\title{
Representation of youth body images in Hilo Teen advertising (Norman Fairclough critical discourse analysis)
}

\author{
Hanna Sundari *), \\ Universitas Indraprasta PGRI \\ Rina Husnaini Febriyanti, \\ Universitas Indraprasta PGRI \\ *) Correspondences author: Jl. Raya Tengah No. 80, Kel. Gedong, Kec. Pasar Rebo, Jakarta Timur 13760, Indonesia; \\ e-mail: hanna.sundari@gmail.com
}

\begin{abstract}
This research is conducted using model of Critical Discourse Analysis (CDA) that stated by Norman Fairclough. This discourse analysis is selected because it is considered to be able to answer the question of the purpose of this research that is formulated which focused on digging up the ideology value on teenager body image that is displayed on the discourse analysis in Hilo Teen advertisement. Fairclough sees a discourse as a social practice and authority which involves particular ideology value whether in explicitly or implicitly. The analysis of Fairclough is centered on text, discourse practice, and sociocultural practice. In this research, discourse analysis text Hilo Teen advertisement is focused on text dimension that involves representation, relation, and identity that is aired on the advertisement and sociocultural context in community scope. The result of this research based on the analysis defines Hilo Teen advertisement describes the body image of teenage girls are thin, slim, tall, and energetic; on the other hand, the body image of teenage boys are thin and tall. This advertisement also displays the problematic and realistic of teenagers who accentuate physical aspect only. Furthermore, Hilo Teen advertisement not only promotes milk product for teenagers but also tries forming a perception and conception on the society (teenagers and parents) about an ideal body shape of teenagers.
\end{abstract}

Key Words: Put body image of teenagers, Hilo Teen Advertisement, and Discourse Analysis Norman Fairclough.

Article History: Received: 29/10/2018; Revised: 30/11/2018; Accepted: 19/12/2018; Published: 25/12/2018

How to Cite (MLA $7^{\text {th }}$ ): Sundari, Hanna and Rina Husnaini Febriyanti. "Representation of youth body images in Hilo Teen advertising (Norman Fairclough critical discourse analysis)." Hortatori Jurnal Pendidikan Bahasa dan Sastra Indonesia 2. 2 (2018): 127-138. Print/Online. Copyrights Holder: Sundari, Hanna and Rina Husnaini Febriyanti. First Publication: Hortatori Jurnal Pendidikan Bahasa dan Sastra Indonesia (2018).

\section{Pendahuluan}

Iklan adalah salah satu alat yang efektif untuk membangun citra bagi yang hendak membentuk persepsi. Masyarakat disuguhkan berbagai macam iklan dalam kehidupan kesehariannya sejak pagi hingga malam. Baik iklan di TV, radio, telepon genggam maupun iklan di pinggir jalan memenuhi ruang pandang dan dengar masyarakat. Remaja dalam iklan menjadi menarik untuk ditelisik karena sebagian besar iklan yang berkaitan dengan remaja menampilkan sosok remaja putri yang mempromosikan berbagai produk seperti pakaian, sepatu, kosmetik remaja, dan lainnya.

Iklan Hilo Teen sebagai promosi produk susu remaja menyasar tidak hanya remaja putri namun juga remaja putra. Iklan Hilo Teen secara tekstual dan visual bersama-sama menyuguhkan tampilan yang memberikan kesan bahwa remaja yang pendek dan gemuk itu buruk, tidak menarik dan tidak diterima di lingkungan. Iklan Hilo Teen menarik untuk dianalisis karena iklan ini tidak hanya mempromosikan produk susu, lebih jauh, juga berusaha membangun konsepsi mengenai citra tubuh (body image) ideal remaja. Dengan metode analisis wacana Norman Fairclough yang juga menghubungkan bahasa dengan konteks 
sosial, penelitian ini dilakukan untuk mendeskripsikan bagaimana citra tubuh (body image) ideal remaja dikonstruksi dalam iklan Hilo Teen.

Tujuan dari penelitian ini dalah untuk upaya untuk mengungkap nilai ideologis dalam citra tubuh (body image) remaja yang disuguhkan dalam wacana teks iklan Hilo Teen. Manfaat dari penelitian ini diharapkan dapat memberikan manfaat dalam bidang analisis wacana khususnya pada nilai-nilai ideoligis yag terkandung didalamnya.

Iklan tidak lepas dari kehidupan keseharian kita. Masyarakat dikelilingi oleh penawaran berbagai barang dan jasa. Iklan menurut O'Guinn, Allen dan Semenik (2003:8, dalam Purwaningwulan, 2011:3) adalah "Advertising is a paid, mass mediated attempt to persuade." (Upaya untuk membujuk melalui media dengan membayar). Iklan menurut Persatuan Perusahaan Periklanan Indonesia (PPPI) adalah segala bentuk pesan tentang suatu produk disampaikan melalui suatu media, dibiayai oleh pemrakarsa yang dikenal, serta ditujukan kepada sebagian atau seluruh masyarakat, sedangkan menurut Kamus Besar Bahasa Indonesia iklan adalah pemberitahuan kepada khalayak mengenai barang dan jasa yang dijual, dipasang di media massa seperti koran dan majalah, atau di tempat-tempat umum

Sementara menurut Renald Kasali, iklan merupakan pesan yang menawarkan suatu produk yang ditujukan kepada masyarakat melalui suatu media (Kasali, 1995 dalam Pujiyanto, 2003:97). Iklan dirancang sedemikian rupa agar menarik minat masyarakat agar terdorong secara suka rela untuk bertindak sesuai yang diinginkan pemrakarsa iklan.

Setidaknya terdapat enam elemen yang terdapat dalam iklan (Purwaningwulan, 2011:5), di antaranya:

1. Bentuk komunikasi yang dibayar

2. Proses identifikasi sponsor

3. Membujuk dan mempengaruhi konsumen

4. Media massa sebagai media penyampai

5. Nonpribadi

6. Pasar sasaran \& konsumen sasaran

Tidak terlalu jauh berbeda, iklan, menurut Ralph Alexander (dalam Pujiyanto, 2003:98) juga memiliki empat pokok batasan, yakni:

1. Penyajian gagasan terhadap suatu barang yang ditampilkan berdasarkan konsep produknya.

2. Iklan ditujukan kepada khalayak yang menjangkau masyarakat kelompok besar (kelompokk pasar).

3. Iklan mempunyai sponsor yang jelas, yakni atas prakarsa perusahaan yang membiayainya.

4. Iklan dikenai biaya penyajian dalam penyebaran, penerbitan, dan penayangan atas biaya perusahaan.

Banyaknya iklan yang dibuat oleh perusaan iklan menyebabkan beragam jenis iklan yang muncul di media. Jenis-jenis iklan (Purwaningwulan, 2011:4-5), di antaranya:

1. Iklan Komersial adalah iklan yang bertujuan untuk mendukung kampanye pemasaran suatu produk atau jasa. Iklan komersial ini sendiri terbagi menjadi beberapa macam, yaitu (Lwin \& Aitchison. 2005):

a) Iklan Strategis: digunakan untuk membangun merek. Hal itu dilakukan dengan mengkomunikasikan nilai merek dan manfaat produk. Perhatian utama dalam jangka panjang adalah memposisikan merek serta membangun pangsa pikiran dan pangsa pasar. Iklan ini mengundang konsumen untuk menikmati hubungan dengan merek serta meyakinkan bahwa merek ini ada bagi para pengguna.

b) IklanTaktis: Memiliki tujuan yang mendesak. Iklan ini dirancang untuk mendorong konsumen agar segera melakukan kontak dengan merek tertentu. Pada umumnya iklan ini memberikan penawaran khusus jangka pendek yang memacu konsumen memberikan respon pada hari yang sama.

2. Iklan Corporate yakni Iklan yang bertujuan membangun citra suatu perusahaan yang pada akhirnya diharapkan juga membangun citra positif produk-produk atau jasa yang diproduksi oleh perusahaan tersebut. Iklan Corporate akan efektif bila didukung oleh fakta yang kuat dan relevan dengan masyarakat, mempunyai nilai berita dan biasanya selalu dikaitkan dengan kegiatan yang berorientasi pada kepentingan masyarakat. Iklan Corporate merupakan bentuk lain dari iklan strategis ketika 
sebuah perusahaan melakukan kampanye untuk mengkomunikasikan nilai-nilai korporatnya kepada publik.

3. Iklan Layanan Masyarakat merupakan bagian dari kampanye social marketing yang bertujuan menjual gagasan atau ide untuk kepentingan atau pelayanan masyarakat. Biasanya pesan Iklan Layanan Masyarakat berupa ajakan, pernyataan atau himbauan kepada masyarakat untuk melakukan atau tidak melakukan suatu tindakan demi kepentingan umum atau merubah perilaku yang tidak baik.

Fungsi iklan dipandang berbeda menurut berbagai sudut pandang. Pujiyanto (2003:98) menegaskan fungsi iklan dalam pemasaran adalah memperkuat dorongan kebutuhan dan keinginan konsumen terhadap suatu produk untuk mencapai pemenuhan kepuasannya. Sementara, bagi orang bisnis, iklan adalah alat pemasaran yang penting yang membantu mengkreasi kesadaran konsumen akan brand (brand awareness) dan loyalitas serta merangsang permintaan. Bagi art director di agensi periklanan, iklan adalah ekspresi kreatif dari suatu konsep mengenai produk atau jasa. Iklan bisa bermakna sesuatu yang berbeda bagi orangorang dengan latar belakang yang berbeda (Purwaningwulan, 2011:3). Namun bagi konsumen, iklan (dalam Subroto) merupakan salah satu strategi pemasaran yang bermaksud untuk mendekatkan barang yang hendak dijual dengan konsumen.

Tindakan membeli oleh masyarakat/konsumen merupakan tujuan dari dirancang dan disebarkannya iklan. Agar iklan mampu merangsang konsumen untuk membeli, Djayakusumah (1982, dalam Pujiyanto, 2003:97-98) sebaiknya memenuhi kriteria yang disingkat menjadi AIDCDA, yakni: Attention (mengandung daya tarik), Interest (mengandung perhatian dan minat), desire (memunculkan keinginan untuk mencoba atau memiliki), conviction (menghadirkan keyakinan untuk membeli), decision (menghasilkan kepuasan terhadap produk), dan action (mengarahkan tindakan untuk membeli).

Pesan yang disampaikan dalam iklan yang memenuhi kriteria di atas setidaknya memiliki aspek informatif dan persuasif. Iklan tidak hanya memberikan informasi yang proporsional dan benar tetapi juga mempunyai daya bujuk sehingga konsumen terdorong untuk membeli. Pesan iklan memiliki daya tarik dan keberhasilan karena beberapa faktor (M. Suyanto, dalam Purwaningwulan, 2011:6):

1. Tokoh/selebtiris, penggunaan figur selebritis amat membantu sebuah produk dalam memperkenalkan dan mempertahankan penjualan. Selebritis tidak saja dari kalangan artis, perfilman tetapi juga olahragawan dan entertainer.

2. Rasa takut, daya tarik ini lebih cenderung untuk memperbaiki motivasi, tindakan pencegahan dan biasanya diaplikasikan dalan dunia kesehatan.

3. Kesalahan, konsep kesalahan sebagai salah satu konsep komunikasi untuk menarik perhatian seseorang terhadap berbagai aktivitasnya yang dianggap lumrah, wajar sehingga menurutnya benar.

4. Komparatif dengan perbandingan yang menjanjikan kemajuan atau keuntungan. Komparasi adalah salah satu cara terbaik dalam memperkenalkan produk serta meningkatkan kesadaran merek, komparasi yaitu membandingkan produk yang satu dengan pesaing atau dengan produk lama.

5. Positif/rasional, cara ini menekankan kepada alasan dasar, manfaat, pengalaman terhadap penggunaan merek. Iklan dengan gaya rasional menekankan fakta, belajar dan ajakan logis serta jaminan yang dapat memuaskan konsumen.

6. Emosional atau persamaan persepsi tentang kebutuhan.Faktor emosional dominan terhadap kebutuhan psikologis, yaitu tentang kepuasan, kenyamanan dan sebagainya.

7. Humor, dapat menjadi metode yang efektif untuk menarik perhatian terhadap iklan.

Sebagai media informasi dan persuasi, iklan haruslah dilandasi dengan etika periklanan. Prinsip kejujuran, pemartabatan manusia, dan tanggung jawab sosial sebaiknya menjadi pertimbangan dalam merancang sebuah iklan. Seringkali iklan dibuat dramatis atau membesar-besarkan keunggulan produk, atau sebaliknya menyembunyikan kebenaran/informasi kelemahan produk, bisa juga memberikan informasi yang bias atau menyesatkan sehingga membingungkan konsumen. Pendek kata, iklan akan disampaikan oleh pemrakarsa dengan cara apapun untuk membuat konsumen membeli. 
Dengan demikian, iklan merupakan pesan yang disampaikan oleh pemrakarsa iklan dengan tujuan untuk menginformasikan ataupun menawarkan produk barang maupun jasa kepada masyarakat/konsumen dengan berlandaskan pada etika periklanan.

Istilah wacana kerap kali terdengar tidak hanya pada bidang kajian linguistik dan komunikasi, namun juga kata "wacana" berkumandang dalam diskusi politik, medis, lingkungan hidup dan bidang ilmu lainnya. Dalam kajian linguistic, wacana dekat dengan istilah lain, yakni teks. Ada yang berpendapat teks merupakan segala hal yang tertulis sedangkan wacana adalah segala sesuatu yang dituturkan. Selain itu, teks identik dengan tulisan panjang dan berkaitan dengan buku-buku, surat atau surat kabar. Kemudian, studi linguistic kekinian memberikan opini yang lebih luas mengenai konsep teks yang diterima secara luas yang meliputi setiap jenis ujaran yang komunikatif (Titscher, dkk, 2009:32). Secara lebih rinci, Vass (1992, dalam Titscher, 2009:42-43) menuliskan makna "wacana" sebagai:

1. (secara umum) tuturan, percakapan, diskusi

2. Penyajian diskursif sederet pemikiran dengan menggunakan serangkaian pernyataan.

3. Serangkaian pernyataan atau ujaran, sederet pertanyaan

4. Bentuk sebuah rangkaian pernyataan/ungkapan yang dapat berupa (arkeologi): wacana ilmiah, puitis, religius.

5. Perilaku yang diatur kaidah yang menggiring kea rah lahirnya serangkaian atau sistem pernyataanpernyataan yang saling terkait (=berbagai bentuk pengetahuan).

6. Bahasa sebagai sesuatu yang dipraktikkan, bahasa tutur.

7. Bahasa sebagai suatu totalitas; seluruh bidang linguistic.

8. Mendiskusikan dan mempertanyakan kriteria validitas dengan tujuan menghasilkan consensus di antara peserta wacana.

Wacana memang memiliki konsep dan pengertian yang luas dan beragam, Jorgensen dan Philips memberikan pengertian yang umum mengenai wacana sebagai cara tertentu untuk membicarakan dan memahami dunia (atau aspek dunia) ini. Secara etimologis kata "wacana" (discourse) berasal dari bahasa latin discurrere yang berarti mengalir ke sana kemari; dari nominalisasi kata diskursus (mengalir secara terpisah) yang dialihkan maknanya menjadi "terlibat dalam sesuatu" atau "memberi informasi tentang sesuatu" (Titscher, 2009:42). Kemudian dalam bahasa Latin kata "diskursus" pada abad pertengahan bermakna percakapan, perdebatan yang aktif, dan keaktifan berbicara. Dalam pandangan linguistik, wacana adalah unit bahasa yang lebih besar dari kalimat.Pengertian wacana dari berbagai sumber dan pendapat ahli (Eriyanto, 2012:2) terangkum sebagai berikut:

1. Collins Concise English Dictionary, 1988: wacana sebagai 1) komunikasi verbal, ucapan, percakapan; 2) sebuah perlakuan formal dari subjek dalam ucapan atau tulisan; 3) sebuah unit teks yang digunakan oleh linguis untuk menganalisis satuan lebih dari kalimat.

2. Longman Dictionary of The English Language, 1984: wacana sebagai 1) sebuah percakapan khusus yang alamiah formal dan pengungkapannya diatur pada ide dalam ucapan dan tulisan; 2) pengungkapan dalam bentuk sebuah nasihat, risalah, dan sebagainya; sebuah unit yang dihubungkan ucapan dan tulisan.

3. J. S Badudu, 2000: wacana adalah 1) rentetan kalimat yang berkaitan, yang menghubungkan proposisi yang satu dengan proposisi yang lainnya, membentuk satu kesatuan sehingga terbentuklah makna yang serasi di antara kalimat-kalimat itu; 2) kesatuan bahasa yang terlengkap dan tertinggi atau terbesar di atas kalimat atau klausa dengan koherensi dan kohesi yang tinggi yang berkesinambungan, yang mampu mempunyai awal dan akhir yang nyata, disampaikan secara lisan atau tertulis.

4. Crystal, 1987: analisis wacana fokus pada struktur yang secara alamiah terdapat pada bahasa lisan, sebagaimana banyak terdapat dalam wacana seperti percakapan, wawancara, komentator, dan ucapan-ucapan.

5. Hawthorn, 1992: wacana adalah komunikasi kebahasaan yang terlihat sebagai sebuah pertukaran di antara pembicara dan pendengar, sebagai sebuah aktivitas personal di mana bentuknya ditentukan oleh tujuan sosialnya.

6. Roger Fowler, 1977: wacana adalah komunikasi lisan atau tulisan yang dilihat dari titik pandang kepercayaan, nilai, dan kategori yang masuk di dalamnya kepercayaan di sini mewakili pandangan dunia; sebuah organisasi atau representasi dari pengalaman. 
7. Foucault, 1972: wacana kadang kala sebagai bidang dari semua pernyataan (statement), kadang kala sebagai sebuah individualisasi kelompok pernyataan dan kadang kala sebagai praktik regulative yang dilihat dari sejumlah pernyataan.

Tidak hanya bidang linguistik, wacana juga mengandung konsep dan pengertian yang hadir dari bidang ilmu lain. Dalam bidang sosiologi, wacana merujuk pada hubungan antara konteks sosial dan pemakaian bahasa. Dalam psikologi sosial, wacana diartikan sebagai pembicaraan, mirip dengan struktur dan bentuk wawancara dan praktik dari pemakainya. Bidang politik memahami wacana sebagai praktik pemakaian bahasa terutama politik bahasa (Eriyanto, 2012:3).

Dengan demikian, wacana dapat dipahami sebagai komunikasi bahasa baik lisan maupun tulisan yang lebih besar dari kalimat dan memiliki unsur kohesi dan koherensi sehingga terbentuk harmonisasi makna, dengan macam-macam bentuk seperti percakapan, wawancara, nasihat, dan lainnya.

Analisis wacana kritis, selanjutnya ditulis CDA, merupakan koreksi dari pandangan konstruktivisme mengenai bahasa dan wacana yang dianggap dapat diatur dan dihidupkan oleh pernyataan-pernyataan yang bertujuan. Analisis wacana, dalam pandangan CDA, tidak hanya ditekankan pada kebenaran/ketidakbenaran struktur bahasa atau proses penafsiran melainkan juga pada konstelasi kekuatan yang terjadi pada proses produksi dan reproduksi makna. Individu tidak dianggap sebagai subjek yang netral yang bisa menafsirkan secara bebas sesuai dengan pikiran nya, karena sangat berhubungan dan dipengaruhi oleh kekuatan sosial yang ada dalam masyarakat (Eriyanto, 2012:6-7).

Menurut Fairclough dan Wodak (dalam Eriyanto, 2012:7) analisis wacana kritis melihat wacana Pemakaian bahasa dalam tuturan dan tulisan sebagai bentuk dari praktik sosial yang menyebabkan sebuah hubungan dialiektis di antara peristiwa diskursif tertentu dengan situasi, institusi, dan struktur sosial yang membentuknya. Karakteristik analisis wacana kritis menurut Teun A Van Dijk, Fairclough dan Wodak (Eriyanto, 2012:8-14) diantaranya:

1. Tindakan: wacana dipahami sebagai sebuah tindakan (action) sehingga wacana diasosiasikan sebagai bentuk interaksi, memiliki tujuan, dan diekspresikan secara sadar dan terkontrol. Seseorang menulis atau berbicara menggunakan bahasa dengan tujuan tertentu dan secara sadar.

2. Konteks: wacana diproduksi, dimengerti, dan dianalisis dalam konteks (latar, situasi, peristiwa, dan kondisi) tertentu. Bahasa dipahami secara keseluruhan, siapa yang mengomunikasikan dengan siapa dan mengapa, melalui medium apa, dan hubungan masing-masing pihak.

3. Historis: wacana diproduksi dalam konteks tertentu dan tidak dapat dimengerti tanpa menyertakan konteks yang menyertainya atau menempatkan wacana dalam konteks historis tertentu.

4. Kekuasaan: analisis wacana kritis juga mempertimbangkan elemen kekuasaan (power) dalam analisisnya. Setiap wacana yang muncul tidak dipandang sebagai sesuatu yang alamiah, wajar dan netral tetapi merupakan bentuk pertarungan kekuasaan. Konsep kekuasaan merupakan salah satu kunci hubungan antara wacana dengan masyarakat.

5. Ideologi: teks, percakapan dan lainnya adalah bentuk praktik ideology atau pencerminan ideologi tertentu. Ideologi dibangun oleh kelompok dominan dengan tujuan untuk memproduksi dan melegitimasi dominansi mereka. Salah satu strategi utama dengan membuat kesadaran kepada khalayak bahwa dominansi itu diterima secara taken for granted.

Lebih lanjut, secara mandiri Ruth Wodak (Titscher dkk, 2009:238-239) mengemukakan prinsipprinsip umum CDA, yakni:

1. CDA berhubungan dengan masalah sosial. Pendekatan ini tidak terkait dengan bahasa maupun penggunaan bahasa secara eksklusif, namun dengan sifat linguistic dari struktur-struktur dan prosesproses sosial dan kultural sehingga CDA bersifat interdisipliner.

2. Relasi kekuasaan berhubungan dengan wacana dan CDA mengaji kekuasaan dalam wacana dan atas wacana.

3. Budaya dan masyarakat secara dialektis berhubungan dengan wacana: masyarakat dan budaya dibentuk oleh wacana sekaligus menyusun wacana. Setiap kejadian tunggal penggunaan bahasa mereproduksi dan mentransformasi masyarakat dan budaya, termasuk relasi kekuasaan.

4. Penggunaan bahasa bisa bersifat ideologis. Untuk memastikannya, teks perlu dianalisis guna meneliti interpretasi, penerimaan dan efek sosialnya.

5. Wacana bersifat historis dan hanya bisa dipahami terkait dengan konteksnya. 
6. Hubungan antara teks dan masyarakat bersifat tidak langsung, termanifestasi melalui perantara, seperti model sosio-kognitif yang kita kembangkan.

7. Analisis wacana bersifat interpretative dan eksplanatoris. Analisis kritis menyiratkan adanya suatu metodologi sistematis dan hubungan antara teks dan kondisi sosial, ideology, dan relasi kekuasaan. Interpretasi bersifat dinamis dan terbuka bagi konteks dan informasi baru.

8. Wacana merupakan bentuk perilaku sosial. CDA dipahami sebagai sebuah disiplin ilmu ilmiah sosial yang eksplisit atas fokus perhatiannya dan cenderung menerapkan penemuannya pada masalah praktis.

Sebagai pertimbangan teoritis atas CDA, Fairclough (dalam Titscher dkk, 2009:241-242) juga mengemukakan konsep-konsep khusus dan pengertiannya yang penting untuk diketahui dalam memahami pendekatan ini, yaitu:

1. Wacana (sebagai kata benda abstrak): penggunaan bahasa dianggap sebagai praktik sosial.

2. Peristiwa diskursif: penggunaan bahasa, dianalisis sebagai teks, praktik diskursif dan praktik sosial.

3. Teks: bahasa tulis dan lisan yang dihasilkan dalam suatu peristiwa diskursif.

4. Interdiskursivitas: penyusunan teks dari beragam wacana dan genre.

5. Wacana (sebagai kata benda yang dapat dihitung) cara menjelaskan (signifying) pengalaman dari suatu perspektif tertentu.

6. Genre: penggunaan bahasa yang diasosiasikan dengan suatu aktivitas sosial tertentu.

7. Tatanan wacana: totalitas praktik diskursif suatu institusi dan hubungan-hubungan di antara praktikpraktik tersebut.

Dengan demikian, analisis wacana kritis dapat dimaknai sebagai analisis tidak hanya aspek linguistic dan pengungkapan maksud tersembunyi dari sang subjek, lebih dari itu, CDA merupakan analisis hubungan-hubungan penggunaan bahasa yang nyata dalam konteks struktur sosial dan budaya yang lebih luas.

Analisis wacana kritis Norman Fairclough didasarkan pada hubungan teks yang mikro dengan konteks masyarakat yang makro. Titik perhatian Fairclough adalah pandangan bahasa sebagai praktik kekuasaan, melihat bagaimana pemakai bahasa membawa nilai ideologis tertentu dibutuhkan analisis yang menyeluruh (Eriyanto, 2012:285).Model analisis yang diajukan Fairclough memadukan linguistik, pemikiran sosial politik dan perubahan sosial, sehingga dikenal sebagai model perubahan sosial (social change).

Dalam pandangan Faiclough, wacana adalah bentuk dari tindakan, seseorang menggunakan bahasa sebagai suatu tindakan pada dunia dan khususnya sebagai bentuk representasi ketika melihat dunia/realitas. Oleh karena itu, model analisis wacana Fairclough mengimplikasikan adanya hubungan timbal balik antara wacana dan struktur sosial (Eriyanto, 2012:286).

Dimensi analisis wacana menurut Norman Fairclough (Eriyanto, 2012: 289-326) terdiri dari:

1. Teks: setiap teks dapat diuraikan dan dianalisis berdasarkan unsur-unsur berikut:

\begin{tabular}{|l|c|}
\hline Unsur & Yang Ingin Dilihat \\
\hline Representasi & $\begin{array}{c}\text { Bagaimana peristiwa, orang, kelompok, situasi, keadaan, } \\
\text { atau apapun ditampilkan dan digambarkan dalam teks (anak kalimat } \\
\text { dan gabungan atau rangkaian antaranak kalimat) }\end{array}$ \\
\hline Relasi & $\begin{array}{c}\text { Bagaimana hubungan antara wartawan (pembuat wacana), } \\
\text { khalayak, dan partisipan berita ditampilkan dan digambarkan dalam } \\
\text { teks }\end{array}$ \\
\hline Identitas & $\begin{array}{c}\text { Bagaimana identitas wartawan, khalayak, dan partisipan } \\
\text { berita ditampilkan dan digambarkan dalam teks. }\end{array}$ \\
\hline
\end{tabular}

2. Discourse practice (praktik wacana): analisis praktik wacana fokus pada bagaimana produksi dan konsumsi teks. Teks dibentuk lewat suatu praktik diskursus yang menentukan bagaimana teks tersebut diproduksi.

3. Sosiocultural practice (praktik sosiokultural): analisis sosiokultural didasarkan pada asumsi bahwa konteks sosial yang ada di luar media memengaruhi bagaimana wacana yang muncul dalam media. Praktik sosiokultural tidak berhubungan langsung dengan produksi teks tetapi menentukan bagaimana teks diproduksi dan dipahami. Sebagai contoh, sebuah teks yang merendahkan posisi 
perempuan, maka itu merupakan representasi ideology patriarki yang ada dalam masyarakat. Level analisis praktik sosiokultural terbagi menjadi:

a) Level situasional: teks dihasilkan dalam suatu kondisi atau suasana yang khas, unik, sehingga satu teks bisa berbeda dengan teks yang lain.

b) Level institusional: bagaimana pengaruh institusi organisasi dalam praktik produksi wacana. Institusi bisa berupa media itu sendiri atau kekuatan-kekuatan eksternal di luar media yang menentukan proses produksi. Pengaruh datang dari pertama a) Iklan tentu ditentukan oleh pemrakarsa iklan yang membiayai proses produksi iklan, b) pembaca/penonton dalam industry media ditunjukkan dalam bentuk rating/share atau oplah, c) persaingan antarmedia, dan d) intervensi institusi ekonomi lain, seperti ekonomi media dan institusi politik.

c) Level sosial: wacana yang muncul dalam media ditentukan oleh perubahan masyarakat. Budaya masyarakat menentukan perkembangan wacana media. Sistem budaya masyarakat menentukan siapa yang berkuasa dan nilai-nilai apa yang dominan dalam masyarakat.

Dimensi analisis wacana Fairclough ini menganalisis teks pada level mikro dengan konteks sosial yang lebih besar. Ketiga dimensi tersebut digambarkan sebagai berikut:

\begin{tabular}{|l|l|}
\hline \multicolumn{1}{|c|}{ TINGKATAN } & \multicolumn{1}{c|}{ METODE } \\
\hline Teks & Critical linguistics \\
\hline Discourse practice & Wawancara mendalam dan news room \\
\hline Sosiocultural practice & Studi pustaka, penelusuran sejarah \\
\hline
\end{tabular}

Melalui analisis wacana Fairclough, wacana dipandang sebagai suatu bidang yang rumit dan kompleks. Bahasa tidak hadir dalam ruang hampa dan tertutup, namun terhubung dan terpengaruh oleh sistem budaya sosial masyarakat pemakai bahasa. Dengan demikian, semua teks selalu terkandung ideologi masyarakat yang tampil secara nyata maupun tersembunyi. Ideologi muncul dalam pilihan kosakata, kalimat dan tata bahasa tertentu. Analisis wacanalah yang bertugas menyingkapnya.

\section{Metode}

Penelitian ini dilakukan dengan model Critical Discourse Analysis (CDA) yang dikemukakan oleh Norman Faiclough. Model analisis wacana ini dipilih karena sekiranya mampu menjawab pertanyaan dan tujuan penelitian yang dirumuskan yang berfokus pada upaya untuk mengungkap nilai ideologis dalam citra tubuh (body image) remaja yang disuguhkan dalam wacana teks iklan Hilo Teen.

Fairclough memandang wacana sebagai praktik sosial dan kekuasaan yang mengandung nilai ideology tertentu baik yang tampil secara eksplisit maupun tersembunyi. Analisis Fairclough dipusatkan pada teks, praktik wacana dan praktik sosiokultural.

Pada penelitian ini, analisis wacana teks iklan Hilo Teen akan difokuskan pada dimensi teks yang meliputi representasi, relasi dan identitas yang ditampilkan dalam iklan dan konteks sosial budaya masyarakat yang melingkupi.

\section{Unit Analisis}

Iklan yang dianalisis dalam penelitian terdiri dari:

1. Iklan Hilo Teen versi "Sale" yang dirilis 3 Maret 2008

2. Iklan Hilo Teen versi "photo session" dirilis 3 April 2008.

3. Iklan Hilo Teen versi "facebook" dirilis 18 Mei 2009.

4. Iklan Hilo Teen versi "Study Tour" yang dirilis pada 21 Juni 2010.

5. Iklan Hilo Teen versi “Tumbuh Tinggi Cuma Sekali” yang dirilis pada 22 Maret 2013.

6. Iklan Hilo Teen versi "Cheerleader" dirilis 10 November 2014.

7. Iklan Hilo Teen versi "Sama Dengan Andika" yang dirilis pada 18 Mei 2015.

Unit analisis berupa 1 unsur kosakata, kalimat dan antarkalimat yang muncul dalam iklan dan 2 tampilan audio dan visual yang berupa suara dan gambar. 


\section{Teknik Pengumpulan dan Analisis Data}

Data dikumpulkan melalui: a) analisis teks lisan, tulisan dan visual yang tampil dalam iklan dan b) studi pustaka untuk menelusuri temuan yang dikaitkan dengan konteks sosial, budaya dan ekonomi masyarakat.

Tahapan analisis (Eriyanto, 2012:327) adalah sebagai berikut:

1. Deskripsi: menguraikan isi dan analisis secara deskriptif atas iklan Hilo Teen.

2. Interpretasi: menafsirkan isi dan analisis pesan iklan Hilo Teen

Ekplanasi: mencari penjelasan atas hasil penafsiran dengan menghubungkannya dengan praktik sosiokultural.

\section{Hasil dan Diskusi}

\section{Gambaran Umum Produk Hilo Teen}

Susu merk Hilo (atau HiLo) diproduksi oleh perusahaan susu Nutrifood Indonesia sejak 2004. Kata "Hilo" dipercaya berasal dari "high" yang diambil dari high calcium (tinggi kalsium) dan low fat (rendah lemak). Susu Hilo hadir dengan beragam varian susu yang diperuntukan untuk berbagai segmen konsuman. Hilo Gold untuk usia di atas 50 tahun, Hilo school untuk anak usia sekolah, Hilo soleha diperuntukan bagi wanita muslim, dan Hilo Teen dengan target sasaran remaja yang sedang tumbuh kembang. Sebagian besar susu Hilo diproduksi dalam bentuk susu bubuk dan dipasarkan dengan sifat promosi rendah lemak namun tinggi kalsium.

Khusus untuk Hilo Teen, produk varian susu yang ini memang menyasar target remaja putra dan putri yang sedang dalam masa pertumbuhan. Berikut pengantar tentang Hilo Teen yang dikutip dari laman resmi hilo-teen.com:

"HiLo Teen, susu tinggi kalsium rendah lemak paling enak untuk tumbuh ke atas, gak ke samping! Masa pertumbuhan kamu membutuhkan asupan kalsium yang lebih tinggi daripada orang dewasa. Tapi, jangan sampai susu yang kamu minum malahan membuat badanmu jadi gendut! Susu HiLo Teen sangat mengerti kebutuhanmu. "

"Berikut kandungan susu HiLo Teen yang bisa membantu kamu: 1. Kalsium yang tinggi $(600 \mathrm{mg}$ per sajian $)$ untuk kebaikan tulangmu, 2. Lemak yang rendah biar ga bikin badan kamu melar ke samping, dan 3. Kombinasi vitamin B1 dan B2 yang memberi kamu tambahan energi untuk beraktivitas. 4. Dilengkapi dengan 74 mineral organik (termasuk kalsium, magnesium, zinc, ferum, fosfor, dan selenium, dll) dari alga merah yang bantu pertumbuhan optimalmu"

"Kini, HiLo Teen dapat dinikmati dalam varian rasa Coklat $(250 \mathrm{~g}, 500 \mathrm{~g}, 750 \mathrm{~g})$, Vanilla Caramel (250g, 750g), Yoghurt Banana (250g), siap minum Coklat $200 \mathrm{ml}$, \& siap minum Orange Biscuit $200 \mathrm{ml} . ”$

"Tumbuh tuh ke atas, ga ke samping!"

\section{Gambaran Umum Iklan Hilo Teen}

Iklan Hilo Teen, berdasarkan penelusuran di Youtube.com, mulai dirilis pada tahun 2008 dengan membuat dua versi sekaligus: remaja putri (versi Sale) dan remaja putra (versi photo session). Namun, pada tahun-tahun berikutnya, setiap tahun iklan yang dirilis tampaknya diperuntukan hanya pada satu sasaran remaja (putra atau putri saja). Berikut rangkuman iklan berdasarkan citra remaja yang ditampilkan:

\begin{tabular}{|l|l|}
\hline Citra Remaja Putra & Citra Remaja Putri \\
\hline Versi "Study Tour" & Versi "Cheerleader" \\
Versi "Tumbuh Cuma satu kali" & Versi "Facebook" \\
Versi "Sama dengan Andika" & Versi "Sale" \\
\hline
\end{tabular}


Berikut adalah transkripsi teks yang diambil dari tiap iklan Hilo Teen:

1. Versi "Sale" (2008)

Hilo Teen Susu Tinggi Kalsium Rendah Lemak khusus untuk remaja

Secara tumbuh tu ke atas gak ke samping

Hilo Teen

2. Versi "Photo Session" (2008)

Haha..Kurang tinggi? Minum Hilo Teen

Kalsiumnya tinggi lemaknya rendah abis

Tumbuh tu ke atas gak ke samping

Hilo Teen

3. Versi "Facebook" (2009)

Pembicara 1, 2 dan 3 : cis...keren keren. Masukin facebook yuk!

Pembicara 1: mana mana...iuh gendut banget..hiiih ulang ulang samping"

"Makanya minum susu Hilo Teen susu tinggi kalsium rendah lemak tumbuh tu ke atas gak ke

Pembicara 2: ini aja aman

Pembicara 1: hah kok aku telinganya doing

Pembicara 2: dasar tembem

"Hilo Teen"

4. Versi "Study Tour" (2010)

Eits gaya pol..bantet..mati gaya dong..minum Hilo Teen susu tinggi kalsium rendah lemak secara tumbuh tu ke atas gak ke samping

5. Versi "Tumbuh Cuma satu kali" (2013)

Pembicara 1: Aku dah sampe, pake baju ijo ya

Pembicara 2: wah kamu kiyut deh. Lihat ke belakang dong cantik

Pembicara 1: hah..oh...kamu tinggi ..keren deh

Pembicara 2: koq tinggi? Turunin viewnya dikit dong

Pembicara 1: loh...hai

"Tumbuh tinggi cuma sekali jangan salah pilih minum Hilo Teen kalsiumnya $2 x$ lebih tinggi tumbuh tu ke atas gak ke samping"

6. Versi "Cheerleader" (2014)

Lola bangun...minum Hilo Teen kalsiumnya paling tinggi rasanya enak rendah lemak lagi..karena tumbuh gak ke atas itu amazing.. Hilo Teen tumbuh tu ke atas gak ke samping.

7. Versi "Sama dengan Andika" (2015)

Ini aku..ini Andika. kita lahir di hari yang sama. Sekolah kita sama, kita suka sama cewe yang sama, kita suka lagu yang sama, kita tumbuh sama-sama. Tapiii.. Andika tumbuh ke atas, aku tumbuh ke samping.

"Belum terlambat untuk tumbuh tinggi. Hilo Teen kalsiumnya $2 x$ lebih tinggi rendah lemak dan enak. Hilo Teen tumbuh tu ke atas gak ke samping”.

Pada tataran teks, representasi melalui ujaran lisan pada iklan Hilo Teen secara umum menampilkan sebuah gambaran keadaan ideal bagaimana seharusnya pertumbuhan remaja baik putra dan putri. Pilihan kosakata yang muncul sangat khas remaja dan menggunakan jargon-jargon sedang banyak dipakai remaja dalam pergaulannya pada masa itu. Contoh penggunaan kosakata yang mengilustrasikan pilihan kata yang banyak dipakai kalangan remaja, diantaranya: secara, lemaknya rendah abis, mati gaya dong. Hal ini menunjukkan produk yang dipromosikan dalam iklan menyasar para remaja. Ditambah, iklan ini merilis dua versi iklan yang diperuntukkan untuk remaja putra (model remaja putra) dan remaja putri (model remaja putri). Dengan demikian, produk susu Hilo Teen ini memang ditujukan baik untuk remaja putra dan putri.

Masih pada tataran tekstual pada iklan Hilo Teen, terdapat beberapa ungkapan-ungkapan yang dapat diasosiasikan sebagai citra atau bentuk tubuh yang tidak ideal atau buruk, seperti: haha..kurang tinggi?, iuh...gendut banget, dasar tembem, bantet..mati gaya, kamu tinggi..keren deh, tapiii Andika tumbuh ke atas aku tumbuh ke samping.Ungkapan demikian dapat ditafsirkan bahwa bertubuh pendek, 
gendut, bantet atau berpipi tembem merupakan bentuk tubuh yang tidak ideal, jelek, dan buruk. Sehingga remaja dengan bentuk tubuh demikian tidak dapat diterima dalam pergaulan/masyarakat. Dan setiap remaja seharusnya berusaha mencapai bentuk tubuh ideal, yakni tidak pendek, tidak gendut, tidak bantet dan tidak berpipi tembem.

Sebenarnya produk susu Hilo Teen telah menuliskan pesan utama berupa tumbuh tu ke atas bukan ke samping dan tinggi kalsium rendah lemak sejak awal kemunculan iklan tahun 2008 sampai sekarang. Baris ekspresi ini telah mempersepsi dalam ruang bawah sadar penonton iklan tentang bagaimana sebuah pertumbuhan fisik remaja yang ideal, lepas dari apakah itu merupakan fakta dan kebenaran yang terbukti secara ilmiah. Melalui pesan utama produk susu Hilo Teen yang disampaikan secara terus menerus dan berulang-ulang, penonton khususnya remaja diajak untuk meyakini dan mempercayai bahwa pertumbuhan fisik remaja dapat diukur dan diamati dari penambahan tinggi badan semata. Penonton digiring untuk percaya bahwa faktor penyebab penambahan tinggi badan manusia (remaja) hanyalah asupan kalsium, menafikan faktor-faktor lain sepert faktor genetika/keturunan. Pesan rendah lemakmemberikan legitimasi bahwa susu Hilo Teen tidak akan menyebabkan peminumnya menjadi gemuk. Suatu yang mungkin paling ditakuti oleh para remaja.

Pada tataran kombinasi antarkalimat, terdapat relasi kontras terutama pada iklan Hilo Teen versi "sama dengan Andika", berikut transkripsinya:

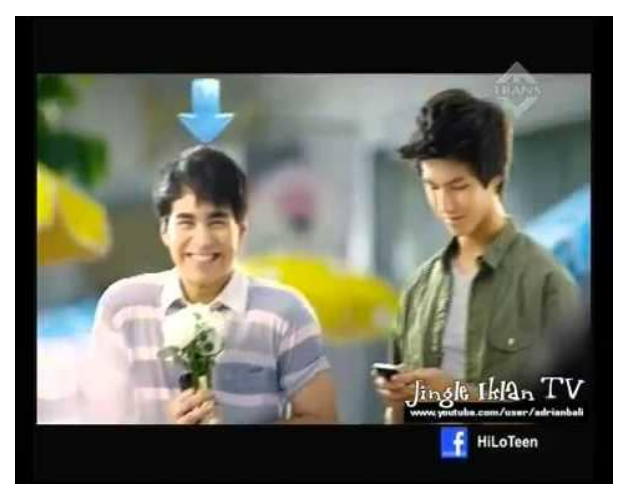

"Ini aku..ini Andika. kita lahir di hari yang sama. Sekolah kita sama, kita suka sama cewe yang sama, kita suka lagu yang sama, kita tumbuh sama-sama. Tapiii.. Andika tumbuh ke atas, aku tumbuh ke samping."

Bentuk relasi kontras ditunjukkan dengan kata hubung "tapi" diucapkan dengan intonasi naik. Hal ini menyiratkan bahwa hal yang dipertentangan merupakan sebuah hal yang besar dan penting. Seolah perbedaan pertumbuhan antara tokoh aku dan Andika mengesampingkan semua persamaan antara mereka dan mempengaruhi kehidupan remaja yang mereka jalani.

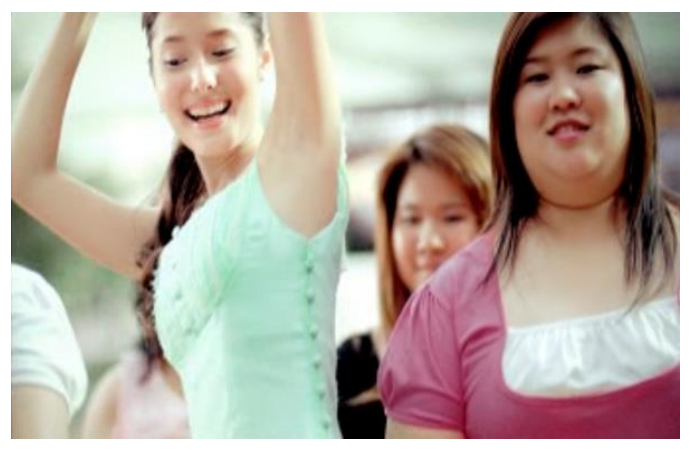

Pada aspek visual, iklan Hilo Teen menampilkan potongan-potongan adegan yang menonjolkan citra ideal remaja putra dan putri secara fisik melalui berbagai simbol. Iklan Hilo teen versi "cheerleader", "facebook", dan "sale" diperuntukkan bagi sasaran konsumen remaja putri. Remaja putri yang ideal secara fisik digambarkan sebagai remaja putri yang bertubuh langsing, kurus, tinggi dan berpipi datar. Simbol yang ditampilkan bahwa remaja putri dengan tubuh ideal tersebut mampu melewati celah-celah sempit, lincah berlari melampaui mereka yang bertubuh gemuk, dan mampu menggapai benda-benda tinggi. Tidak 
seperti mereka yang bertubuh pendek sulit menggapai benda di posisi tinggi, dan yang bertubuh gemuk menjadi lambat. Simbol lain yang ditampilkan yakni, gelas susu yang datar berubah menjadi langsing, sesuai siluet tubuh wanita dengan pinggang yang ramping. Transformasi bentuk gelas menyimbolkan sesuatu yang salah/buruk menuju sesuatu yang benar/baik. Berbadan gemuk itu salah/buruk, sementara yang benar/baik adalah berbadan langsing, ramping dan tinggi.

Iklan Hilo Teen versi "study tour", "tumbuh Cuma 1x", "sama dengan Andika", dan "photo session" ditujukan bagi sasaran konsumen remaja putra. Iklan menampilkan berbagai peristiwa yang menunjukkan bahwa menjadi remaja putra bertubuh pendek itu memalukan dan tidak menarik bagi lawan jenis. Simbol tindakan berupa remaja pria yang berfoto menggunakan pijakan ataupun yang tidak dapat menaruh tas nya dalam celah barang bagian atas di dalam bus, kemudian mereka mendapat cemoohan dari kawan-kawan. Adegan lain menampilkan remaja putra yang berbadan pendek dan gemuk tidak diharapkan dan tidak menarik bagi lawan jenis (remaja putri). Remaja putri lebih mendambakan remaja putra yang berbadan tinggi karena dianggap lebih keren. Adegan ditampilkan dengan satu-lawan-satu (one-to-one image) sehingga penonton disuguhkan gambar secara langsung citra mana yang ideal dan tidak ideal.

Dengan demikian, berdasar pada analisis di atas diperoleh beberapa kesimpulan.Pertama, iklan Hilo Teen baik pada tataran tekstual maupun visual lebih menampilkan dan mengasosiasikan citra tubuh (body image) ideal remaja putra dan putri yang diwujudkan dalam bentuk tubuh ideal remaja putri itu ramping, langsing dan tinggi dan remaja putra itu tinggi dan kurus. Dari citra iklan ditunjukkan melalui tuturan maupun gambaran visual bahwa pertumbuhan masa remaja (pubertas) itu seharusnya ditunjukkan dengan penambahan tinggi badan bukan berat badan.

Kesimpulan kedua, iklan Hilo Teen menyajikan kehidupan dan segala problematika sosial para remaja (putra dan putri). Penggunaan pilihan kosakata yang digunakan kalangan remaja (bahasa gaul) dan tema-tema cerita berkisar seputar remaja, seperti pergi study tour, mencari teman kencan, menjadi anggota cheerleader, sesi foto untuk buku tahunan sekolah. Hal tersebut menunjukkan bahwa iklan ini memang tentang dan untuk remaja. Selain itu, iklan Hilo juga sensitif dalam mengilustrasikan problematika klasik yang dihadapi para remaja, seperti: sulitnya mendapat pacar, rebutan baju, cemoohan teman, tidak percaya diri (minder) karena faktor fisik, dan sebagainya. Sehingga secara keseluruhan iklan Hilo Teen tidak hanya memasarkan produk susu untuk remaja tetapi juga menggambarkan hiruk pikuk kehidupan remaja.

Ketiga, iklan-iklan Hilo Teen memberikan persepsi dan konsepsi kepada masyarakat khususnya kalangan remaja tentang bagaimana bentuk fisik yang ideal seorang remaja baik secara tekstual maupun visual. Remaja merupakan periode transisi masa anak-anak menjadi dewasa, dicirikan dengan pencapaian kemandirian dan pencarian identitas yang menonjol. Iklan Hilo Teen seolah memberikan identitas setidaknya secara fisik bagi remaja. Sehingga remaja memiliki tolak ukur mengenai bagaimana bentuk fisik/tubuh mereka yang ideal agar mereka diterima paling tidak di kalangan mereka sendiri.

Konsep tentang tubuh ideal dibangun berdasarkan konstruksi sosial masyarakat dan berubah seiring waktu. Sehingga kata "cantik/tampan" akan dimakna secara berbeda pada masyarakat satu dan lainnya. Dalam literatur peradaban barat, konsep bentuk tubuh khususnya perempuan diproduksi dan direproduksi oleh kelas yang dominan (Muwarni, 2010: 16). Bagaimana seseorang menilai tubuh bergantung pada sistem budaya dan sosial diluar dirinya. Dengan demikian, seseorang akan menyesuaikan dirinya berdasarkan pada konsep yang dibangun lingkungan sosial budaya dimana dia berada.

Kalangan remaja yang sedang dalam proses pencarian identitas dan jati diri secara tidak sadar menerima pesan iklan yang didengar/ditontonnya sebagai suatu kebenaran utuh. Pada saat bersamaan, industri (barang) dalam hal ini produk susu dan industri periklanan berusaha memengaruhi dan meyakinkan konsumen bahwa apa yang ditampilkan dalam iklan merupakan realitas sosial yang patut dijadikan tolak ukur.

\section{Simpulan}

Iklan merupakan dunia citra dan pencitraan yang hendak membentuk persepsi konsumen/masyarakat sesuai keinginan pemrakarsa iklan. Berdasarkan hasil analisis, iklan Hilo Teen menggambarkan citra tubuh (body image) remaja putri itu ramping, langsing, tinggi dan enerjik; sementara citra tubuh remaja putra yang ideal itu tinggi dan kurus. Iklan juga menyajikan realitas dan problematika remaja yang lebih menonjolkan aspek fisik semata. Lebih lanjut, iklan Hilo Teen tidak sekedar 
mempromosikan produk susu untuk remaja tetapi juga berusaha membentuk persepsi dan konsepsi pada masyarakat (remaja dan orang tua) mengenai bentuk tubuh remaja yang ideal.

Berdasarkan hasil penelitian dapat dipahami bahwa konsep tentang bentuk tubuh sesungguhnya datang dari luar diri seseorang, yakni dari sistem sosial budaya yang dianut dan diyakini masyarakat atau dikonstruksi oleh kelas yang lebih dominan. Sehingga, dibalik persepsi dan konsepsi citra tubuh ideal yang sedang dibentuk melalui iklan, terdapat industri-industri (kapitalis) yang terus mengambil keuntungan.

\section{Ucapan Terima Kasih}

Terima kasih kepada semua pihak yang membantu penulis dalam menyelesaikan artikel hasil riset ini sehingga bisa diterbitkan di Jurnal Hortatori.

\section{Daftar Rujukan}

Eriyanto. Analisis Wacana: Pengantar Analisis Teks Media. Yogyakarta: PT. LKIS Printing Cemerlang, 2012.

Jorgensen, Marianne W, and Louise J Phillips. Analisis Wacana: Teori dan Metode. Yogyakarta: Pustaka Pelajar, 2010.

Muwarni, Endah. "Konstruksi "Bentuk Tubuh Perempuan" dalam Iklan Televisis." Jurnal Ilmu Komunikasi, 2010: Volume II, Nomor 1, hal. 10-18.

Pujiyanto. "Strategi Pemasaran Produk Melalui Media Periklanan." Nirmana, 2003: Vol. 5 No. 1 Januari hal. 96-109.

Purwaningwulan, Melly Maulin. "Daya Tarik Pesan Iklan Humor." Majalah Ilmiah UNIKOM, 2011Vol, 10 No, 1.

Subroto, Setyawati. "Etika Periklanan." tanpa tahun.

Titscher, Stefan, Michael Mayer, Ruth Wodak, and Eva Vetter. Metode Analisis Teks dan Wacana. Yogyakarta: Pustaka Pelajar, 2009.

http://www.hilo-teen.com/behindthescene/about

https://www.behance.net/gallery/872520/HiLo-Teen-TV-Commercial-Sale 